\title{
Pengaruh Discovery Learning terhadap Kesadaran Metakognisi dan Hasil Belajar Peserta Didik
}

\section{(The Effect of Discovery Learning toward Student's Metacognitive Awareness and Cognitive Learning Achievement)}

\author{
Dini Aji Pangestuti*, Rini Rita T. Marpaung, Neni Hasnunidah \\ Program Studi Pendidikan Biologi Universitas Lampung, Jl. Prof. Dr. Soemantri Brojonegoro No. 1 Bandar Lampung, Indonesia \\ *Corresponding author: diniajipangestuti@gmail.com
}

Received: 14 August 2019 - Accepted: 27 September 2019 - Published: 30 September 2019

\begin{abstract}
This study was conducted to find out the effect of discovery learning on student's metacognitive awareness and cognitive learning achievement. The population of this research was all of the 11 th grade MS (Mathematics and Science Program) students of Sumberejo 1 Senior High School. The research sample were students of 11th MS-1 and MS-3 class taken by cluster random sampling technique. This study was quasi-experimental with Pretest Post-test Non-Equivalent Control Group Design. In this study, student's metacognitive awareness was measured by using MAI (Metacognitive Awareness Inventory) and SEMLI-S (Self-Efficacy and Metacognition Learning Inventory-Science). Meanwhile, student's cognitive learning achievement was measured by using cognitive test. The data were analyzed statistically by independent sample t-test respectively at 5\% significance level. The results showed that the discovery learning model significantly influenced student's metacognitive awareness and cognitive learning achievement with significant value of each were 0,000 . Through this research, we found that the discovery learning model significantly influenced student's metacognitive awareness and cognitive learning achievement rather than discussion method.
\end{abstract}

Keywords discovery learning, metacognitive awareness, cognitive learning achievement

\begin{abstract}
ABSTRAK Penelitian ini bertujuan untuk menganalisis pengaruh penggunaan model discovery learning terhadap kesadaran metakognisi dan hasil belajar kognitif peserta didik. Populasi penelitian ini adalah seluruh peserta didik kelas XI SMA Negeri 1 Sumberejo. Sampel penelitian ini adalah peserta didik kelas XI MIPA 1 dan XI MIPA 3 yang dicuplik dengan teknik cluster random sampling. Desain penelitian kuasi eksperimen ini adalah Pretest Post-test Non Equivalent Control Group Design. Pada penelitian ini, kesadaran metakognisi peserta didik diukur menggunakan MAI (Metacognitive Awareness Inventory) dan SEMLI-S (Self-Efficacy and Metacognition Learning Inventory-Science). Sementara itu, hasil belajar kognitif diukur menggunakan tes. Data dianalisis secara statistik menggunakan independent sample t-test dengan tingkat kepercayaan 5\%. Hasil penelitian menunjukkan bahwa model discovery learning berpengaruh signifikan terhadap kesadaran metakognisi dan hasil belajar kognitif dengan nilai signifikansi sama yaitu 0,000. Berdasarkan hasil penelitian, dapat disimpulkan bahwa terdapat pengaruh yang signifikan dari penggunaan model discovery learning terhadap kesadaran metakognisi dan hasil belajar peserta didik dibandingkan dengan metode diskusi.
\end{abstract}

Kata Kunci discovery learning, kesadaran metakognisi, hasil belajar kognitif

(C) 2019 Department of Biology Education, Universitas Pendidikan Indonesia

\section{PENDAHULUAN}

Memasuki Abad ke-21, sistem pendidikan menghadapi tantangan yang sangat kompleks. Akibatnya, sistem pendidikan di seluruh dunia dituntut untuk mempersiapkan generasi yang mampu menjawab tantangan Abad ke-21 melalui pendidikan berkualitas. Pendidikan berkualitas dapat meningkatkan berbagai keterampilan termasuk keterampilan berpikir. Pemberdayaan keterampilan berpikir penting dilakukan agar peserta didik mampu menganalisis situasisituasi baru dan menerapkannya pada kehidupan mereka sehari-hari (Nurmaliah \& Khairil, 2017). Salah satu jenis keterampilan berpikir adalah metakognisi. Rahman dan
Phillips (2006) menyatakan bahwa keterampilan berpikir yang diperlukan pada era globalisasi terkait dengan kemampuan thinking about thinking dan dikenal dengan metakognisi. Metakognisi adalah pemahaman peserta didik tentang cara kerja memori mereka sendiri (Velzen, 2016).

Pemberdayaan metakognisi pada peserta didik memerlukan model pembelajaran yang dapat memfasilitasinya. Salah satu model pembelajaran yang diyakini dapat membangun metakognisi adalah discovery learning. Darmawan \& Wahyudin (2018) menyatakan bahwa dalam proses pembelajaran model discovery peserta didik dituntut untuk menemukan jawaban atas pertanyaan yang diberikan melalui pengalaman belajarnya sendiri. 
Pengalaman belajar mandiri melatih peserta didik untuk menggunakan keterampilan berpikirnya sendiri. Metakognisi sebagai salah satu keterampilan berpikir peserta didik, juga berhubungan dengan hasil belajar peserta didik. Kubiszyn \& Borich (2013) menyatakan bahwa hasil belajar peserta didik yang diperoleh dari tes yang mengacu pada taksonomi Bloom revisi Anderson tidak hanya menggambarkan pencapaian tujuan belajar yang diinginkan, tetapi juga proses berpikir peserta didik untuk mencapai hasil tersebut.

Metakognisi terbagi atas aspek kesadaran dan keterampilan metakognisi. Corebima (2009) menyatakan bahwa kesadaran metakognisi merupakan kesadaran atas kontrol proses kognitif. Sedangkan keterampilan metakognisi adalah kemampuan peserta didik dalam memaparkan jawaban tes akademik berbentuk esai. Instrumen yang digunakan untuk mengukur kesadaran dan keterampilan metakognisi berbeda. Danial (2010) menyatakan bahwa skor kesadaran metakognisi diukur melalui Metacognitive Awareness Inventory (MAI) yang dikembangkan oleh Schraw \& Dennison (1994). Sedangkan keterampilan metakognisi diukur dengan menggunakan Metacognitive Strategy Instruction (MSI) yang dikembangkan oleh Corebima (2009).

Beberapa penelitian menyatakan bahwa selain meningkatkan metakognisi, model discovery learning juga meningkatkan hasil belajar kognitif peserta didik. Penelitian Windasari (2016) mengenai pengaruh model discovery learning terhadap kesadaran metakognisi dan hasil belajar kognitif peserta didik pada materi sistem reproduksi menunjukkan bahwa rerata skor kesadaran metakognisi dan hasil belajar peserta didik yang melakukan pembelajaran dengan model discovery lebih tinggi dibandingkan dengan model konvensional. Penelitian Balim (2009) mengenai pengaruh penggunaan discovery learning pada pembelajaran sains dan teknologi kelas 7 sekolah dasar di kota Izmir, Turki menunjukkan terjadi peningkatan hasil belajar kognitif secara signifikan pada peserta didik kelas eksperimen.

Berdasarkan hasil studi pendahuluan yang dilaksanaan pada bulan Maret 2018 di SMA Negeri 1 Sumberejo melalui hasil angket dan wawancara terhadap seluruh pendidik yang mengampu mata pelajaran biologi, didapatkan fakta bahwa model discovery learning sering digunakan dalam pembelajaran. Namun, $67 \%$ pendidik belum melaksanakan pembelajaran dengan sintaks yang sesuai. Pendidik jarang melaksanakan sintaks stimulasi, verifikasi, dan generalisasi. Adapun sintaks discovery learning menurut Darmawan \& Wahyudin (2018) adalah: 1) stimulasi; 2) identifikasi masalah; 3) pengumpulan data; 4) pengolahan data; 5) pembuktian; dan 6) menarik kesimpulan.

Penggunaan model discovery learning yang belum optimal karena ketidaklengkapan sintaks pembelajaran ada kemungkinan berpengaruh terhadap capaian hasil belajar. Trend data hasil belajar kognitif peserta didik di SMA Negeri 1 Sumberejo belum optimal. Rerata nilai ujian akhir semester ganjil biologi kelas XI selama tiga tahun terakhir adalah 59,3; 60,1; dan 60,7. Selain itu, penilaian metakognisi peserta didik di SMA Negeri 1 Sumberejo belum pernah dilakukan oleh pendidik.

Salah satu materi pokok dalam pembelajaran biologi adalah sistem gerak. Adapun kompetensi dasar materi sistem gerak adalah "Menganalisis hubungan antara struktur jaringan penyusun organ pada sistem gerak dalam kaitannya dengan bioproses dan gangguan fungsi yang dapat terjadi pada sistem gerak manusia. Kompetensi pada materi sistem gerak cocok untuk dilaksanakan menggunakan pembelajaran berbasis penemuan. Sesuai dengan pendapat Wilke \& Straits (2001) bahwa model discovery learning dirancang untuk membelajarkan bioproses dalam sains sembari memperkenalkan atau memperkuat materi pembelajaran.

Berdasarkan uraian masalah yang telah dikemukakan, perlu dilakukan penelitian lebih lanjut mengenai proses pembelajaran menggunakan model discovery learning. Selain itu, penelitian mengenai pengaruh penggunaan model pembelajaran discovery learning terhadap kesadaran metakognisi dan hasil belajar kognitif khususnya pada materi sistem organ, misalnya sistem gerak masih jarang dilakukan. Oleh karena itu peneliti tertarik untuk meneliti "Pengaruh Discovery learning Terhadap Kesadaran Metakognisi dan Hasil Belajar Kognitif Peserta Didik".

\section{METODE}

Penelitian ini dilaksanakan pada materi sistem gerak di bulan Januari semester genap tahun pelajaran 2018/2019 di SMA Negeri 1 Sumberejo, Kabupaten Tanggamus, Lampung. Populasi dalam penelitian ini adalah seluruh peserta didik kelas XI MIPA. Adapun sampel penelitian ini adalah peserta didik kelas XI MIPA 3 (32 orang) dan XI MIPA 1 (31 orang) yang diperlakukan sebagai kelas eksperimen dan kelas kontrol. Sampel dicuplik dengan menggunakan metode cluster random sampling. Penelitian kuasi eksperimen ini menggunakan Pretest Post-test Non Equivalent Control Group Design. Adapun struktur desain penelitian tertera pada Tabel 1.

Tabel 1. Desain pretest-postest kelompok non-ekuivalen

\begin{tabular}{cccc}
\hline Kelompok & Pretest & $\begin{array}{c}\text { Variabel } \\
\text { bebas }\end{array}$ & Posttest \\
\hline $\mathrm{E}$ & $\mathrm{Y}_{1}$ & $\mathrm{X}$ & $\mathrm{Y}_{2}$ \\
\hline $\mathrm{C}$ & $\mathrm{Y}_{1}$ & - & $\mathrm{Y}_{2}$ \\
\hline & & \multicolumn{2}{c}{ (Diadaptasi dari Ary, 2000) }
\end{tabular}

Keterangan:

$\mathrm{Y} 1=$ Pretest

$\mathrm{E}=$ Kelompok eksperimen

$\mathrm{C}=$ Kelompok kontrol

$\mathrm{X}=$ Perlakuan pada kelas eksperimen

$\mathrm{Y} 2=$ Posttest

Kelompok eksperimen melakukan pembelajaran dengan model discovery learning, sedangkan kelompok kontrol belajar dengan metode diskusi. Kedua kelompok subjek diberi tes hasil belajar kognitif (pretest/posttest) pada Materi Pokok Sistem Gerak. Sedangkan kesadaran metakognisi peserta didik diukur dengan menggunakan angket yang merupakan gabungan dari MAI yang diadaptasi dari Schraw dan Denisson (1994) dan SEMLI-S yang diadaptasi dari Thomas et al. (2008). Angket metakognisi diberikan sebelum dan sesudah pembelajaran berlangsung pada kedua kelompok subjek. 
Sebelum instrumen tes hasil belajar digunakan, terlebih dahulu dilakukan analisis validitas isi, konstruk, dan empiris serta uji reliabilitas. Analisis validitas isi dan konstruk oleh pembimbing, sedangkan validitas empiris di laksanakan dengan validasi soal di SMA Negeri 1 Talangpadang, Tanggamus. Kemudian dihitung tingkat validitasnya dengan rumus korelasi Product Moment dan reliabilitas dengan Alpha Cronbach. Data kesadaran metakognisi dan hasil belajar kognitif diuji secara statistik dengan Independent Sample t-Test dengan tingkat kepercayaan 5\%. Adapun uji prasyarat berupa uji normalitas dengan Kolmogorov-Smirnov dan uji homogenitas menggunakan Levene's test.

\section{HASIL DAN PEMBAHASAN}

\section{Pengaruh Penggunaan Model Pembelajaran Discovery learning Terhadap Kesadaran Metakognisi Peserta Didik}

Hasil penelitian menunjukkan bahwa terdapat perbedaan pencapaian kesadaran metakognisi sebelum dan sesudah pembelajaran. Perbedaan rerata kesadaran metakognisi peserta didik pada model discovery learning dan metode diskusi ditunjukkan oleh Gambar 1. Berdasarkan gambar, diketahui bahwa terdapat peningkatan kesadaran metakognisi pada peserta didik baik yang belajar dengan model discovery learning maupun peserta didik yang belajar dengan metode diskusi. Peningkatan keseluruhan indikator kesadaran metakognisi tertinggi terjadi pada peserta didik yang belajar dengan model pembelajaran discovery.

Hasil independent sample t-test (Tabel 2) menunjukkan ada perbedaan kesadaran metakognisi yang signifikan antara pembelajaran dengan menggunakan model discovery learning dan metode diskusi. Hal ini diyakini karena pengalaman belajar peserta didik pada kegiatan pembelajaran model discovery. Peserta didik diberi stimulus oleh pendidik terkait materi yang dipelajari sehingga peserta didik termotivasi untuk menyelesaikan permasalahan pada LKPD. Kemudian peserta didik merumuskan hipotesis dan melakukan pengamatan terhadap hubungan struktur jaringan, fungsi dan menganalisis gangguan fungsi pada sistem gerak. Peserta didik berdiskusi untuk menyusun rencana (planning) mengenai strategi dan waktu yang diperlukan untuk menyelesaikan tugas. Hal ini sesuai dengan pendapat Delvecchio (2011) bahwa indikator perencanaan dalam metakognisi muncul pada saat peserta didik menggambarkan pengetahuan yang relevan dengan masalah, mengidentifikasi tujuan, menyusun rencana dan mengatur sumber referensi serta waktu dalam penyelesaian masalah.

Kesadaran metakognisi dalam penelitian ini meningkat juga dimungkinkan karena adanya kegiatan pengolahan data dalam pembelajaran melalui model discovery. Peserta didik memantau kemajuan proses penyelidikan dan menuliskan hasil pengamatan dengan cara mereka sendiri sesuai hasil temuannya. Menurut Brown 1987 (dalam Lee \& Baylor, 2006) keterampilan berpikir peserta didik dalam memantau digambarkan dengan penilaian dalam penggunaan strategi yang dilakukan peserta didik. Peserta didik dapat melakukan self-assessment, misalnya "bagaimana seharusnya saya melakukannya," dan "informasi apa yang dibutuhkan untuk menyelesaikan tugas yang diberikan" dan lain lain.

Kegiatan pembelajaran pada sintaks verifikasi dan generalisasi discovery learning pada penelitian ini dapat meningkatkan kesadaran metakognisi peserta didik, terutama indikator evaluasi. Pada proses pembelajaran, hasil temuan penyelidikan dievaluasi kebenarannya dengan membandingkannya terhadap literatur dan diskusi kelompok/kelas. Hal ini melatih kemampuan menganalisa dan mengevaluasi penyelesaian masalah-masalah tentang materi biologi serta kemampuan peserta didik dalam menyanggah. Flavel, 1985 (dalam Munandar, 2014) menyatakan bahwa metakognisi dapat muncul saat peserta didik diminta untuk berdiskusi, membuat kesimpulan, pertimbangan, dan keputusan yang benar sehingga diperlukan kehati-hatian dalam memantau dan mengatur proses kognitifnya.

Tabel 2. Hasil Uji Statistik Kesadaran Metakognisi

\begin{tabular}{lcccc}
\hline Perlakuan & $\bar{X} \pm$ Sd & $\begin{array}{c}\text { Uji } \\
\text { Normalitas }\end{array}$ & $\begin{array}{c}\text { Uji } \\
\text { Homogenit } \\
\text { as }\end{array}$ & $\begin{array}{c}\text { Uji } \\
\text { Perbedaan } \\
\text { Rerata }\end{array}$ \\
\hline Discovery & $78,81 \pm 6$, & Sig $0,85>$ & & Sig (2- \\
Learning & 36 & 0,05 & Sig $0,54>$ & tailed $)$ \\
\cline { 1 - 2 } Diskusi & $67,81 \pm 6$, & Sig $0,92>$ & 0,05 & $0,00<$ \\
& 03 & 0,05 & & 0,05 \\
\hline
\end{tabular}

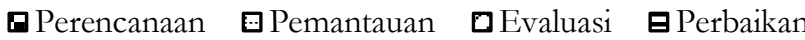

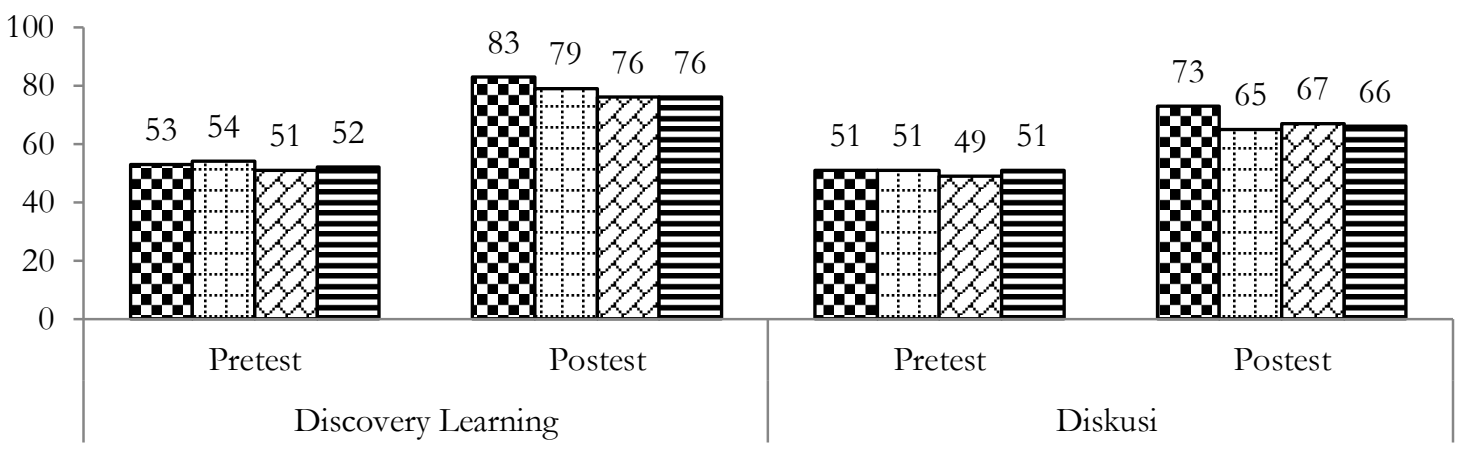

Gambar 1. Rerata Kesadaran Metakognisi Peserta Didik per Indikator 
Selain meningkatkan kesadaran metakognisi peserta didik dalam mengevaluasi, kegiatan peserta didik dalam sintaks verifikasi dan generalisasi discovery learning juga dapat meningkatkan keterampilan peserta didik dalam melakukan perbaikan. Hal ini dimungkinkan karena pada proses pembelajaran, kesalahan dari temuan dalam penyelidikan yang tidak sesuai dengan dengan referensi atau hasil diskusi diperbaiki dengan cara mencari alternatif lain. Peserta didik juga mengevaluasi serta memperbaiki kinerja kelompok, pembagian tugas, dan alokasi waktu sesuai dengan pengalaman yang didapatkan selama pembelajaran. Hal ini didukung oleh pernyataan Brown, 1987 (dalam Lee \& Baylor, 2006) yang menyatakan bahwa proses pembelajaran yang melibatkan proses modifikasi rencana sebelumnya mengenai sasaran, strategi, dan pendekatan pembelajaran mencerminkan keterampilan peserta didik untuk melakukan perbaikan.

\section{Pengaruh Penggunaan Model Pembelajaran Discovery learning Terhadap Hasil Belajar Peserta Didik}

Hasil penelitian menunjukkan bahwa terdapat perbedaan pencapaian hasil belajar kognitif sebelum dan sesudah pembelajaran. Perbedaan rerata hasil belajar kognitif peserta didik pada model discovery learning dan metode diskusi ditunjukkan oleh Gambar 2. Berdasarkan gambar, diketahui bahwa terdapat peningkatan hasil belajar kognitif pada peserta didik baik yang belajar dengan model discovery learning maupun peserta didik yang belajar dengan metode diskusi. Peningkatan keseluruhan indikator kesadaran metakognisi tertinggi terjadi pada peserta didik yang belajar dengan model pembelajaran discovery. Kim et al. (2008) menyatakan bahwa metakognisi penting dikembangkan dalam pembelajaran untuk meningkatkan kemampuan berpikir tingkat tinggi. Dengan kata lain, metakognisi terkait dengan pencapaian hasil belajar peserta didik. Peserta didik yang memiliki metakognisi tinggi kemungkinan hasil belajarnya juga tinggi. Hal ini sesuai dengan fakta hasil penelitian bahwa metakognisi peserta didik pada kelas discovery learning tinggi.
Hasil independent sample t-test (Tabel 3) menunjukkan ada perbedaan hasil belajar kognitif yang signifikan antara pembelajaran dengan menggunakan model discovery learning dan metode diskusi. Selain itu, dimensi proses kognitif kemampuan berpikir tingkat tinggi (C4, C5, C6) pada pembelajaran dengan model discovery learning mengalami peningkatan lebih tinggi dibandingkan dengan pembelajaran metode diskusi (Gambar 2). Hal ini diyakini karena pengalaman belajar peserta didik pada kegiatan pembelajaran model discovery.

Kegiatan peserta didik pada sintaks stimulasi dan identifikasi masalah discovery learning pada penelitian ini dapat meningkatkan hasil belajar kognitif peserta didik. Peserta didik diberi stimulus oleh pendidik terkait materi yang dipelajari, sehingga mendorong peserta didik untuk melakukan eksplorasi dan aktivitas belajar lainnya yang mengarah pada persiapan pemecahan masalah. Kegiatan pembelajaran ini meningkatkan dimensi kognitif peserta didik terutama dimensi menganalisis (C4) dan mencipta (C6) karena peserta didik diberi kesempatan untuk menghubungkan pengetahuan yang telah ia miliki dengan pengetahuan maupun konsep baru dan memadukannya untuk membentuk suatu hipotesis. Hal ini sesuai dengan pendapat Holmes \& Hoffman (2000), yang menyatakan bahwa salah satu karakteristik discovery learning yaitu peserta didik menciptakan, mengintegrasikan, dan mengeneralisasi pengetahuan melalui eksplorasi dan pemecahan masalah. Selain itu, Zane (2013) menyatakan bahwa identifikasi merupakan sub-skill dari kemampuan analisis. Sehingga dengan membiasakan peserta didik untuk melakukan identifikasi masalah dapat melatih kemampuan menganalisis.

Tabel 3. Hasil Uji Statistik Kesadaran Hasil Belajar Kognitif

\begin{tabular}{|c|c|c|c|c|}
\hline Perlakuan & $\bar{X} \pm \mathrm{Sd}$ & $\begin{array}{c}\text { Uji } \\
\text { Normalitas }\end{array}$ & $\begin{array}{c}\text { Uji } \\
\text { Homogenita } \\
\text { s }\end{array}$ & $\begin{array}{c}\text { Uji } \\
\text { Perbedaan } \\
\text { Rerata }\end{array}$ \\
\hline Discovery & 76,09 & Sig $0,90>$ & \multirow{3}{*}{$\begin{array}{c}\text { Sig } 0,74> \\
0,05\end{array}$} & \multirow{3}{*}{$\begin{array}{c}\text { Sig }(2- \\
\text { tailed) } 0,00 \\
<0,05\end{array}$} \\
\hline Learning & $\pm 4,82$ & 0,05 & & \\
\hline Diskusi & $\begin{array}{r}60,65 \\
\pm 4,63\end{array}$ & $\begin{array}{c}\text { Sig } 0,76> \\
0,05\end{array}$ & & \\
\hline
\end{tabular}

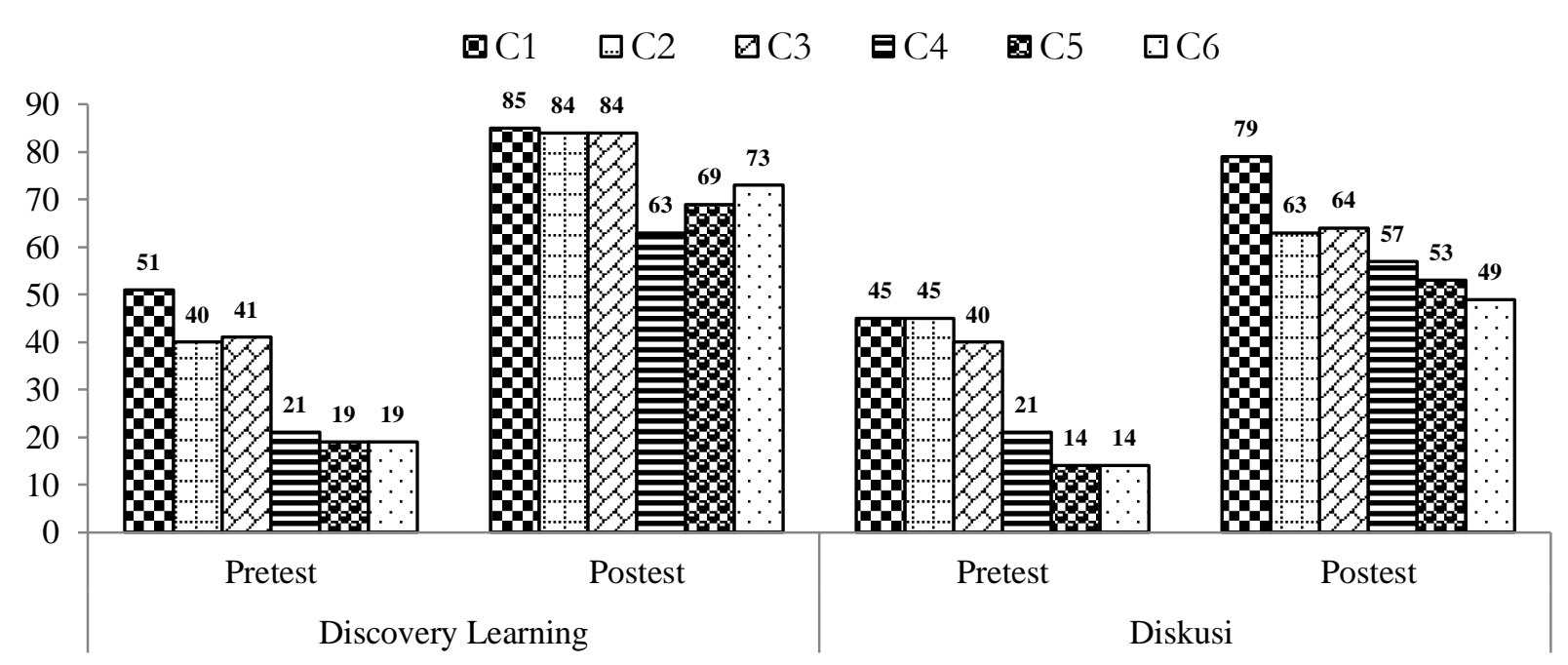

Gambar 2. Rerata Hasil Belajar Kognitif per Dimensi Proses Kognitif 
Dimensi hasil belajar kognitif tingkat tinggi mengevaluasi (C5) dalam penelitian ini meningkat juga dimungkinkan karena adanya pengalaman belajar dalam kegiatan pengumpulan dan pengolahan data, serta verifikasi. Peserta didik melakukan kegiatan penyelidikan mengenai macam-macam jaringan dan fungsinya pada tulang, struktur persendian pada rangka tubuh dan fungsi kemudahan gerak rangka penyusun sendi, serta mekanisme kerja otot dalam mendukung berbagai gerakan. Selanjutnya peserta didik menganalisa informasi yang relevan untuk menyelesaikan permasalahan pada LKPD. Peserta didik mengolah data hasil penyelidikan dan mengevaluasi kesesuaiannya dengan hipotesis yang telah dibuat. Kemudian peserta didik melakukan kegiatan verifikasi untuk menjustifikasi hasil analisis data dengan literatur maupun persepsi kelompok lain melalui diskusi kelas. Hal ini sesuai dengan hasil penelitian Rubiyanto et al. (2016) bahwa aspek mengevalausi dilatih saat peserta didik memilah informasi yang didapat dan kesesuaiannya dengan referensi, misalnya buku dan internet untuk mendapatkan informasi yang benar.

Langkah terakhir pada kegiatan pembelajaran model discovery menyimpulkan (generalisasi) menjadikan peserta didik terlatih untuk memiliki pengalaman belajar mencipta. Peserta didik membuat kesimpulan mengenai kebenaran konsep dari penyelesaian masalah dalam LKPD dengan memadukan hasil dari kegiatan penyelidikan dan mengevaluasi kebenaran. Hal ini diperkuat oleh pendapat Anderson et al. (2001) bahwa dimensi kognitif mencipta merupakan kegiatan memadukan bagian-bagian untuk membentuk sesuatu yang baru dan koheren atau untuk membuat suatu produk yang orisinal.

Pencapaian hasil belajar kognitif peserta didik yang tinggi pada pembelajaran dengan model discovery learning juga didukung dengan tanggapan positif peserta didik melalui angket. Peserta didik menyatakan materi yang dipelajari peserta didik melalui proses pembelajaran discovery secara mandiri lebih mudah diingat dan bermakna. Hal ini disebabkan karena pembelajaran menyenangkan, mudah diikuti, tidak memberatkan, dan tidak membosankan sehingga menambah kejelasan materi biologi. Subini (2012: 126) menyatakan salah satu faktor yang mempengaruhi hasil belajar peseta didik adalah faktor internal (faktor dari dalam diri peserta didik). Faktor internal yang mempengaruhi hasil belajar peserta didik diantaranya adalah motivasi belajar.

\section{SIMPULAN}

Berdasarkan hasil penelitian dan pembahasan, maka dapat disimpulkan bahwa terdapat pengaruh yang signifikan dari penggunaan model discovery learning terhadap kesadaran metakognisi dan hasil belajar peserta didik. Pencapaian seluruh indikator kesadaran metakognisi yang belajar dengan model discovery learning lebih tinggi dibandingkan peserta didik yang belajar dengan menggunakan metode diskusi. Selain itu, pembelajaran dengan model discovery learning.

\section{REFERENSI}

Ary, D., Jacobs, L.C. \& Razaviech, A. (2010). Introduction to Research Education. Ohio: Cengange Learning.
Anderson, L.W., Krathwohl, D.R., Airiasian, W., Cruikshank, K.A., Mayer, R.E., \& Pintrich, P.R. (2001). A Taxonomi for Learning. Teaching \& Assessing: A Revision of Bloom's Taxonomi of Educational Objectives. New York: Addison Wesley Longman, Inc.

Balim, A.G. (2009). The effects of discovery learning on students' success andinquiry learning skills. Eurasian Journal of Educational Research, 35: 1-20.

Corebima, A.D. (2009). Metacognitive Skill Measurement Integrated in Achievement Test. Makalah disajikan dalam Third International Conference on Science and Mathematics Education (CosMed). Malaysia, 10-12 November 2009.

Danial, M. (2010). Kesadaran metakognisi, keterampilan metakognisi dan penguasaan konsep kimia dasar. Jurnal Ilmu Pendidikan, 17 (3): 225-229.

Darmawan, D. \& Wahyudin, D. (2018). Model Pembelajaran di Sekolah. Bandung: PT Remaja Rosdakarya.

Delvecchio, F. (2011). Student's use metacognitive skills while problem solving in school chemistry. Disertasi: tidak diterbitkan.

Holmes, B.T. and Hoffman, P.S. (2000). Elicit, Engage, Experience, Explore: Discovery Learning in Library Instruction. Faculty Publications, University of Nebraska-Lincoln Libraries. 28 (4): 313-322.

Kim, B., Park, H., \& Baek, Y. (2008). Not just fun, but serious strategies: using metacognitive strategies in game based learning. Journal of Computer and Education. 52 (4): 800-810.

Kubiszyn, T., \& Borich, G. (2013). Educational Testing and Measurement: Classroom Application and Practice 10th edition. Hoboken, NJ.: John Wiley \& Sons, Inc.

Lee, M, \& Baylor, A.L. 2006. Designing Metacognitive Maps for Web-Based Learning. Educational Technology and Society, 9 (1): 344-348.

Munandar, H. (2014). Meningkatakan kemampuan pemecahan masalah matematik siswa melalui pembelajaran dengan pendekatan metakognitif. Makalah disajikan dalam Seminar Nasional Pendidikan Matematika, Seminar Nasional Bandung: Program Pasca Sarjana STKIP Siliwangi Bandung.

Nurmaliah, C. \& Khairil. (2017). Analisis keterampilan metakognisi siswa dengan penerapan strategi pembelajaran pemberdayaan berpikir melalui pertanyaan pada siswa SMP Negeri 2 Banda Aceh. Makalah disajikan dalam Prosiding Seminar Nasional Biotik 2017, Aceh.

Rahman, S., \& Phillips, J. A. (2006). Hubungan antara kesedaran metakognisi, motivasi dan pencapaian akademik pelajar universiti. Jumal Pendidikan Malaysia 31: 21-39.

Rubiyanto, B.A. J., Marjono, dan Prayitno, B.A. (2016). Penerapan model discovery learning pada materi ekosistem untuk meningkatkan kemampuan berpikir tingkat tinggi siswa kelas X SMA. Bio-pedagogi. 5 (1): 614.

Schraw, G. \& Dennison, R.S. (1994). Assesing metacognitive awareness. Contemporary Educational Psychology, 19(4): 460-475.

Subini, N. (2012). Psikologi Pembelajaran.Yogyakarta: Mentari Pustaka. 
Thomas, G., Anderson, D., \& Nashon, S. (2008). Development of an instrument designed to investigate elements of science students' metacognition, self-efficacy and learning processes: The SEMLI-S. International Journal of Science Education. 30 (13): 1701-1724.

Velzen, J.V. (2016). Metacognitive Learning (Advancing Learning by Developing General Knowledge of the Learning Process). New York: Springer International Publishing.

Wilke, R.R. \& Straits, W.J. (2005). Practical advice for teaching inquiry-based science process skills in biological sciences. The American Biology Teacher, 67(9): 534-540.

Windasari, C. (2016). Pengaruh Model Guided Discovery Terhadap Kesadaran Metakognitif dan Hasil Belajar Kognitif Peserta Didik pada Materi Sistem Reproduksi Manusia di MAS Babun Najah Banda Aceh. Jurnal Biotik. 4 (1): 66-74.

Zane, T.W. (2013). Implementing Critical Thingking with Signature Assignments. Salt Lake: Salt Lake Community College. 